\title{
Definition of factors influencing innovative development of enterprises of timber processing complex
}

\author{
Igor Igorevich Shanin \\ Voronezh State University of Forestry and Technologies named after G.F. Morozov, \\ 394087, Voronezh, Timiryazeva St., 8 \\ kingoao@mail.ru
}

\begin{abstract}
The forest branch is one of the most perspective directions of the Russian industry. It is caused by several factors among which there is low cost of raw materials and a broad sales market both within the country and beyond its limits.

Innovative development of the timber processing complex has to become a considerable factor of diversification of economy. The forest branch opens ample opportunities for small and medium business which can be applied the forces and the ideas. Also application of biotechnologies can contribute to the development of the branch. Biotechnological methods still are in Russia at a stage of scientific development and only begin to take root in practice. They are applied, for example, when carrying out selection work. Now, business wood acts as the main product of the branch - its share among the total amounts of the taken-out forest production makes from 75 to $80 \%$. The direction of all timber processing complexes of Russia is considered logging. In the late eighties of the last century, the Soviet Union in the world ranking conceded in wood export volumes only to America. After a number of economic transformations of the last decades, Russia has moved in this list to the 6-7th place. As well as in other industries of the Russian Federation, which are based on production and the subsequent renewal of raw materials in forestry, the main revenue is formed of sale of the raw materials for export. Developments of the factors by definition, interfering innovative development of the timber industry enterprises, are presented in the article.
\end{abstract}

Keywords - innovative development, factors, enterprises, timber processing complex, ecology.

\section{INTRODUCTION}

Lumbermen in ten years have endured a powerful collapse of the export markets in the global financial crisis of 2008-2009, accession to WTO, decrease in rates for export of the raw wood in 2012, the collapse of Russian ruble in 2014-2015 and have entered an era of import substitution and export-orientedness.

The purpose of "Strategy-2020" was good: to satisfy the needs of domestic market for high-quality and competitive timber and paper production of domestic production, to ensure ecological safety, stable satisfaction of public needs for resources and services of the wood. However these purposes and tasks wander from the document to the document. The idea to develop domestic market of timber consumption and paper production is not new. The vector was set in 2002 by the order of the government in "The main directions of development of the forest industry", and the model was from the Soviet period when domestic market consumed the main volume of the made production. Orientation to requirements of the markets in the future and analysis of trends is a fundamental difference of "Strategy-2030" from predecessors.

To achieve the objects set by "Strategy-2030", the Russian forest complex has to solve five problems. This increases the extent of use of forest raw materials, raises efficiency of reforestation, improves investment attractiveness for creation of new productions, simplifies receiving wood resources and going beyond the limits of domestic market of sale of finished goods.

In 2002 nobody predicted that China will become the main consumer of domestic forest production, then the market of the CIS was guided. In 2008, "Strategy-2020" also staked on the CIS as the main consumer of the Russian forest product, and the last place was allocated to China.

But in 2017, it was already clear that China was the main trade partner of Russia for the next decades and it was difficult to ignore this tendency. And it is even not important who to whom is more necessary, it has also coincided. But China took care of the forest raw safety long ago, and in 15-20 years the plantation woods in South America, Oceania, in which it invested hundreds of millions dollars and which can replace the Russian raw materials and semi-finished products, will keep up. By then Russia will just have a new forest strategy.

\section{RESULTS AND DISCUSSION}

Let us consider the loudspeaker of financial result of activity of the timber industry enterprises for January-August, 20162017, presented in figure 1 . 


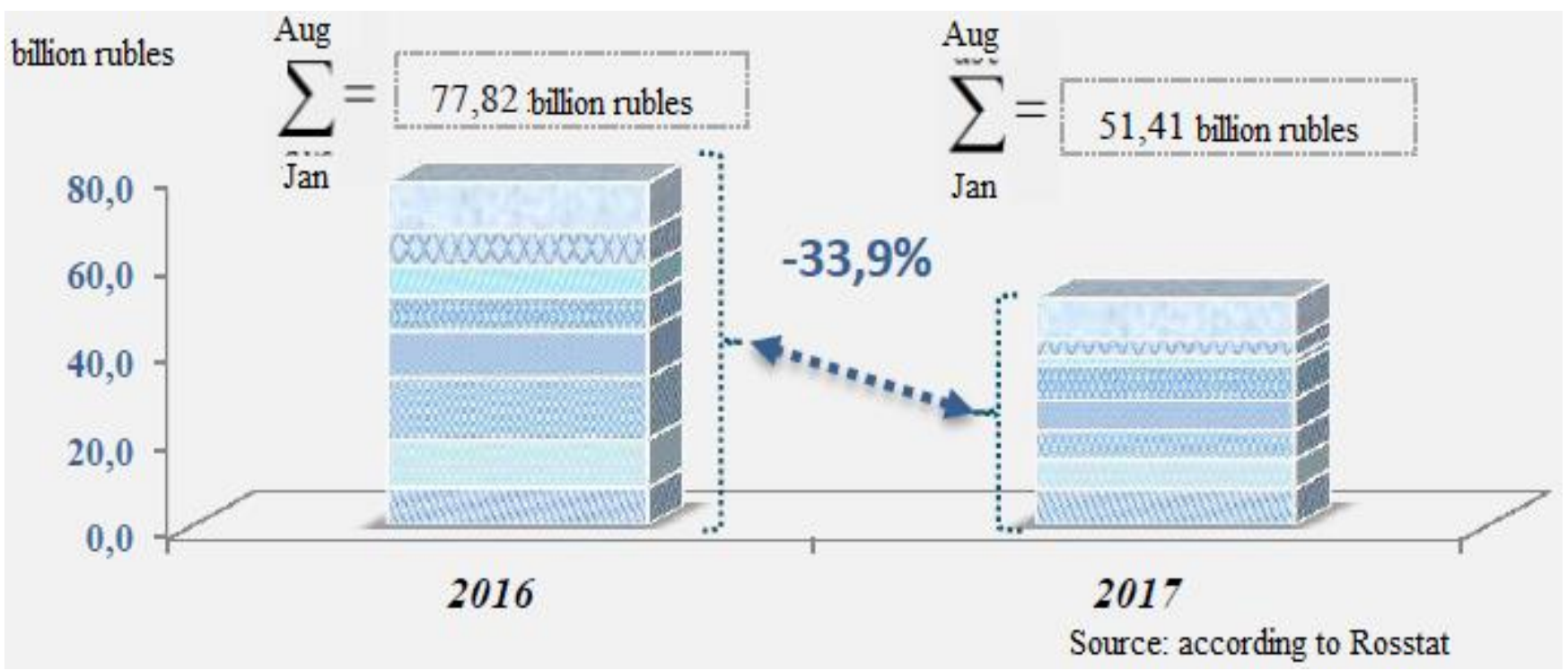

Fig. 1. Dynamics of financial result of activity of timber industry enterprises for January-August, 2016-2017

The balanced financial result for January-August, 2017, decreased by 26,41 billion rubles in comparison with the same period of the last year and was 51,4 billion rubles (143 organizations got a profit of 56,1 billion rubles, and 40 - had a loss for the sum of 4,6 billion rubles). At the same time, financial cut in August, 2017, showed growth by 5 billion rubles; concerning July, 2017, and made 9,1 billion rubles. Specific weight of the profitable organizations in August, 2017 was $78,1 \%$ (increased by 1,6 items by July, 2017).
In our opinion, the most essential one is formation of the group of factors influencing innovative development of the enterprises of the timber processing complex created by the degree of belonging to the sphere of activity: namely, factors of scientific, production, ecological activity of the enterprises. The complexity and multilevelness of interrelations of these factors demand dividing them into the groups presented in table 1.

TABLE I. THE FACTORS INFLUENCING INNOVATIVE DEVELOPMENT OF THE ENTERPRISES

\begin{tabular}{|c|c|c|c|}
\hline Groups of factors & $\begin{array}{l}\text { The characteristic of factors in } \\
\text { the field of innovation activity of } \\
\text { the enterprise }\end{array}$ & $\begin{array}{l}\text { The characteristic of factors in the } \\
\text { field of production activity of the } \\
\text { enterprises }\end{array}$ & $\begin{array}{l}\text { The characteristic of factors } \\
\text { in the field of ecological } \\
\text { activity of the enterprises }\end{array}$ \\
\hline Financial and economic & $\begin{array}{l}\text { The amount of financing for } \\
\text { research works }\end{array}$ & $\begin{array}{l}\text { The amount of financing for } \\
\text { production activity }\end{array}$ & $\begin{array}{l}\text { The amount of financing for } \\
\text { ecological activity }\end{array}$ \\
\hline Material and technical & $\begin{array}{l}\text { The factors interfering conditions of } \\
\text { implementation of research activity, } \\
\text { namely, the backwardness of fixed } \\
\text { assets, information security, } \\
\text { organizational support and } \\
\text { necessary resources applied for } \\
\text { implementation of research and } \\
\text { development }\end{array}$ & $\begin{array}{l}\text { The factors interfering normal } \\
\text { conditions for implementation of } \\
\text { production activity of the enterprises. } \\
\text { Here it is possible to note } \\
\text { backwardness of fixed assets, } \\
\text { information security, organizational } \\
\text { support and necessary resources } \\
\text { necessary for production of innovative } \\
\text { production. }\end{array}$ & $\begin{array}{l}\text { The factors interfering normal } \\
\text { conditions for implementation } \\
\text { of ecological activity of the } \\
\text { enterprises. Here it is possible } \\
\text { to note the backwardness of } \\
\text { fixed assets, information } \\
\text { security, organizational support } \\
\text { and necessary resources } \\
\text { attracted to the ecology-focused } \\
\text { production. }\end{array}$ \\
\hline Natural & $\begin{array}{l}\text { The ecological factors interfering } \\
\text { implementation of research activity. } \\
\text { Backwardness of processing } \\
\text { equipment which using is } \\
\text { impossible to introduce into } \\
\text { innovations taking into account } \\
\text { ecological aspects, the ecological } \\
\text { program }\end{array}$ & $\begin{array}{l}\text { The ecological factors interfering } \\
\text { implementation of production activity. } \\
\text { The wildfires putting thousands of } \\
\text { hectares of the wood out of } \\
\text { commission; absence of ecological } \\
\text { service; need for training of personnel } \\
\text { for ecological area. }\end{array}$ & $\begin{array}{l}\text { The natural factors interfering } \\
\text { implementation of ecological } \\
\text { activity. } \\
\text { Irrational use of wood } \\
\text { resources, application of } \\
\text { inefficient actions for renewal } \\
\text { of forest resources. }\end{array}$ \\
\hline Informational & $\begin{array}{l}\text { Resources necessary for } \\
\text { implementation of research activity. }\end{array}$ & $\begin{array}{l}\text { Resources and data arrays necessary } \\
\text { for production activity }\end{array}$ & $\begin{array}{l}\text { The factors interfering } \\
\text { obtaining necessary } \\
\text { information and data for } \\
\text { implementation of innovative } \\
\text { development of the enterprises }\end{array}$ \\
\hline
\end{tabular}


Formation of approaches to innovative development of the enterprises of the timber processing complex acts as a priority task within the formed national economy. In this regard carrying out regular assessment of a condition of the innovative environment of the enterprises, taking into account ecological factors, identification of the existing problems and opportunities of the ways of introduction of innovations, estimation of prospects of development, is necessary.

Having considered the existing approaches of innovative development of the enterprises, the author has offered the technique allowing to estimate innovative development of the enterprises. The offered technique is based on bases of innovative development of the enterprise as sets of 3 components (scientific, production, ecological), each of which includes 4 groups of factors (financial and economic, material, natural, information groups). When calculating a total integrated indicator low values of the counted indicators are considered and the recommendations of their increase are developed.

For definition of extent of influence of factors on innovative development of the enterprises, it is necessary to carry out calculations of factorial influence on the basis of a total integrated indicator. Calculation of integrated total begins with calculation of a planned target:

$$
I_{\text {plan. }}=\frac{x_{i}-x_{i}^{\min }}{x_{i}^{\max }-x_{i}^{\min }}
$$

where $\mathrm{x}_{\mathrm{i}}$ - value of indicator $\mathrm{x}$;

$x_{i}^{\text {min }}$ - minimum value of indicator $\mathrm{i}$;

$x_{i}^{\max }$ - maximum value of indicator $\mathrm{i}$.

The value of planned targets varies from 0 to 1 .

At the following stage, the value of a total integrated indicator on each group pays off:

$$
P_{A}=\frac{\sum_{i}^{B} I_{\text {plan } i}}{B}
$$

where B - quantity of indicators in each of three groups of factors.

All counted values of an integrated indicator on each group are characterized by the equal importance. The total integrated indicator varies from 0 to 1 . The closer the received values of an integrated indicator to 1 , the more intensively the corresponding directions of innovative activity of the enterprise develop.

Calculation of a total integrated indicator of innovative development of the enterprise, taking into account ecological factors, is carried out using the following formula:

$$
\Pi_{i r}=\frac{b_{1}}{B} \times R_{F E}+\frac{b_{2}}{B} \times R_{M T}+\frac{b_{3}}{B} \times R_{P},
$$

where $b_{1,2,3}$ - quantity of indicators in the financial and economic set;

B - total of the used indicators for assessment of innovative development;

R_FE - the index on a financial and economic integrated indicator;

\section{R_MT - the index on a material integrated indicator; \\ R_P - the index on a natural integrated indicator.}

As weight coefficients, when calculating total integrated indicators of each group, the author used shares of quantity of the indicators when calculating each group in total of the indicators used during assessment of the corresponding indicator are accepted. The sum of weight coefficients should not exceed 1; thus, the equal contribution of indicators of each set of factors to total assessment is provided, according to the received shares. After that, the integrated indicator of innovative development of the enterprise is defined by calculation of the arithmetic-mean value.

TABLE II. WEIGHT COEFFICIENTS OF ASSESSMENT OF AN INTEGRATED INDICATOR OF INNOVATIVE DEVELOPMENT OF THE ENTERPRISE

\begin{tabular}{|l|l|}
\hline \multicolumn{1}{|c|}{ Range of values } & \multicolumn{1}{c|}{$\begin{array}{c}\text { The characteristic of a condition of innovative development at the } \\
\text { enterprise }\end{array}$} \\
\hline $0-0,2$ & $\begin{array}{l}\text { The condition is estimated as menacing. } \\
\text { Factors constitute danger to the enterprise, and innovative } \\
\text { development is considered as the main threat during implementation } \\
\text { of innovative activity }\end{array}$ \\
\hline $0,2-0,45$ & $\begin{array}{l}\text { The condition is estimated as unsatisfactory. } \\
\text { Factors create obstacles during implementation of innovative activity }\end{array}$ \\
\hline $0,45-0,7$ & $\begin{array}{l}\text { The condition is estimated as satisfactory. } \\
\text { Factors of innovative development are changeable and it is necessary } \\
\text { to watch dynamics of their development. } \\
\text { Implementation of innovative activity is possible. }\end{array}$ \\
\hline $0,7-0,85$ & $\begin{array}{l}\text { The condition is estimated as good, promoting effective } \\
\text { implementation of innovative activity. }\end{array}$ \\
\hline $0,85-1,0$ & $\begin{array}{l}\text { The condition is estimated as favorable. } \\
\text { The innovative environment of the enterprise is absolutely balanced. }\end{array}$ \\
\hline
\end{tabular}

Formation of favorable conditions for innovative development of the enterprises of the timber processing complex is the priority perspective direction during creation of the system of the innovative timber processing complex of the country. For this reason, there is a need for regular assessment of a condition of the innovative environment of the timber 
industry enterprises; the identifications are a problem and opportunities on the way of their formation, assessment of prospects of development. Results of calculations of integrated indicators by each of four groups of factors are presented in table 3 .

TABLE III. RESULTS OF CALCULATIONS OF AN INTEGRATED INDICATOR OF INNOVATIVE DEVELOPMENT OF THE TIMBER INDUSTRY ENTERPRISES FOR GROUPS OF FACTORS DURING 2012-2017

\begin{tabular}{|c|c|c|c|c|c|c|c|}
\hline \multirow[t]{2}{*}{ Name of a component } & \multirow{2}{*}{$\begin{array}{l}\text { Name of group of } \\
\text { factors }\end{array}$} & \multicolumn{6}{|c|}{ Value of an integrated indicator } \\
\hline & & 2012 & 2013 & 2014 & 2015 & 2016 & 2017 \\
\hline \multirow{4}{*}{$\begin{array}{l}\text { Scientific and technical } \\
\text { component of innovative } \\
\begin{array}{l}\text { development } \\
\text { enterprises }\end{array}\end{array}$} & Financial and economic & 0,319 & 0,214 & 0,381 & 0,416 & 0,483 & 0,428 \\
\hline & Material and technical & 0,212 & 0,197 & 0,214 & 0,319 & 0,341 & 0,392 \\
\hline & Natural & 0,571 & 0,531 & 0,594 & 0,572 & 0,612 & 0,622 \\
\hline & Informational & 0,514 & 0,631 & 0,563 & 0,611 & 0,587 & 0,574 \\
\hline \multirow{4}{*}{$\begin{array}{ll}\text { Production component of } \\
\text { innovative development of } \\
\text { the enterprises }\end{array}$} & Financial and economic & 0,221 & 0,219 & 0,276 & 0,318 & 0,373 & 0,411 \\
\hline & Material and technical & 0,294 & 0,273 & 0,319 & 0,407 & 0,394 & 0,422 \\
\hline & Natural & 0,319 & 0,476 & 0,511 & 0,497 & 0,583 & 0,691 \\
\hline & Informational & 0,461 & 0,492 & 0,518 & 0,471 & 0,567 & 0,529 \\
\hline \multirow{4}{*}{$\begin{array}{l}\text { Ecological component of } \\
\text { innovative development of } \\
\text { the enterprises }\end{array}$} & Financial and economic & 0,328 & 0,362 & 0,293 & 0,322 & 0,370 & 0,384 \\
\hline & Material and technical & 0,174 & 0,149 & 0,256 & 0,317 & 0,402 & 0,462 \\
\hline & Natural & 0,356 & 0,492 & 0,414 & 0,518 & 0,541 & 0,553 \\
\hline & Informational & 0,492 & 0,471 & 0,518 & 0,562 & 0,538 & 0,582 \\
\hline
\end{tabular}

\section{CONCLUSION}

From table 2 it is visible that the lowest values of an integrated indicator are observed in financial and economic and material groups compared to factors that demonstrate insufficient financing of scientific activity of the enterprise and security with the qualified personnel. The highest values of integrated indicators for the period are observed in information and the natural group, for which total the integrated index does not fall below mark 0,5 .

The research of a condition of innovative development of the enterprises of the timber processing complex has allowed one to define the restrictions interfering introduction of innovations, namely:

- insufficiency of financing of a scientific and technical component. Financing at the expense of the budgetary funds distributed by funds. However, their share, directed to a research of problems of the timber processing complex rather low in comparison with other scientific directions, remains the main source of science funding throughout already a long period of time. Also the unwillingness of potential investors to put in the scientific sector of the timber processing complex, owing to high cost of wood resources and the competition from China and other exporters, is observed;

- low level of the scientific and technical personnel occupied with research and development;

- low level of material equipment of scientific and technical, and production directions. It should be noted that a high degree of wear of material and technical resources, the existing low rates of updating of the fixed assets characterized their physical and obsolescence, incomplete use of the available production capacities;

- a lack of information resources and difficulty of its processing and synchronization in development of innovative activity;
- the low value of specific weight of the enterprises of the timber processing complex introducing the ecology-focused innovations is observed; there is a tendency to reduction of this specific weight here. Low level of efficiency of financing of ecological actions;

- at the insufficient level, commercialization of innovations as a consequence of backwardness of integration scientific and technical and production components of innovative development of the enterprises takes place;

- insufficient efficiency of exchange of information between subjects of innovative activity of the enterprises.

\section{Acknowledgment}

«The reported study was funded by RFBR according to the research project № 18-010-00318»

\section{References}

[1] T.L. Bezrukova, Yu.N. Stepanova, I.I. Shanin, Yu.V. Busarina, S.Yu Nesterov, "Aspect - oriented key - index based regional business entities evaluation framework," European Research Studies Journal, 2017, V. 20, No. 3B, pp. 183-192.

[2] F. de Melo, V.V. Maslennikov, E.V. Popova, T.L. Bezrukova, I.V. Kyksova, "Quantitative analysis in economics based on wavelet transform: a new approach,” Asian Social Science, 2015, vol. 11, № 20, pp. 66-73.

[3] I.I. Shanin, O.A. Boris, "Modeling operation of mechanism of holistic management of technological processes at enterprise," IOP Conf. Series: Materials Science and Engineering, no. 327, 2018, 022095 doi:10.1088/1757-899X/327/2/022095.

[4] S.S. Morkovina, M.V. Drapalyuk, P.M. Evlakov, N.A. Safonova, "Innovational mechanisms of biotechnologies support in forest sector for providing economic security of the state," Asian social science, 2015, V. 11, № 20, pp. 41-48.

[5] S.S. Morkovina, E.A. Kolesnichenko, V.A. Spesivtsev, A.V. Ivanova, "Principles of innovational startup selection for e-platforms placement," Mediterranean Journal of Social Sciences, 2015, V. 6, № 6, pp. 201-211.

[6] Y.N. Stepanova, I.V. Sibiryatkina, V.E. Sukhova, "Risk aspects of creation of investment e-platform as a tool of support for small innovative enterprises,” Asian Social Science, 2015, V. 11, № 20, pp. 127-133. 
[7] T. Tereshkina, S. Tereshchenko, T.L. Bezrukova, E. Drevaleva, O. Pecherskaya, "Improvement of methods of analysis of effectiveness of stock management at industrial enterprises," In the collection: Integration and Clustering for Sustainable Economic Growth Ser. "Contributions to Economics", 2017, pp. 461-467.

[8] T. Tereshkina, E. Drevaleva, S. Tereshchenko, T. Bezrukova, O. Pecherskaya, "Improvement of methods of analysis of effectiveness of stock management at industrial enterprises," Contributions to Economics, 2017, № 9783319454610, pp. 461-467.

[9] T.L. Bezrukova, O.V. Lashkareva, G.A. Kozhakhmetova, Z.A. Dulatbekova, D.M. Mukhiyayeva, "Creation of innovations-oriented clusters in the sphere of agro-industrial complex as a perspective direction of foreign economic cooperation of Russia and Europe," Contributions to Economics, 2017, № 9783319606958, p. 589-596.

[10] I.V. Gashenko, D.G. Romanov, S.G. Vokina, T.L. Bezrukova, Y.A. Kozenko, "Theoretical and methodological aspects of innovation development in modern economic systems," Contemporary Economics. 2016, vol. 10, № 4, p. 363-372.

[11] S. Morkovina, T. Bezrukova, I. Sibiryatkina, N. Bukhtoyarov, E. Leontyev, "Risk factors for the development of entrepreneurship in forest sector of Russia," In the collection: Proceedings of the 29th International Business Information Management Association Conference - Education
Excellence and Innovation Management through Vision 2020: From Regional Development Sustainability to Global Economic Growth 29 , Education Excellence and Innovation Management through Vision 2020: From Regional Development Sustainability to Global Economic Growth, 2017, p. 1975-1981

[12] S.S. Morkovina, Y.M. Sokolinskaya, N.M. Bukhtoyarov, N.A. Safonova "Deformation factors of the entrepreneurship development in the industry segments of the economy of the Russian Federation," European Research Studies Journal, 2017, V. 20, № 3B, pp. 403-411.

[13] S.S. Morkovina, A.S. Natsubidze, M.S. Irizepova, N.G. Sinyavsky, V.V. Chashchin, "Transnational business as a manifestation of the integration of the global economy and a driving force of its development," Contemporary Economics, 2016, V. 10, № 4, pp. 311-322.

[14] Kusakina O.N., Bannikova N.V., Morkovina S.S., Litvinova T.N. "State stimulation of development of small entrepreneurship in developing countries," European Research Studies Journal, 2016, V. 19, № 2, Special Issue. pp. 276-284.

[15] S.S. Morkovina, M.V. Drapalyuk, P.M. Evlakov, N.A. Safonova "Innovational mechanisms of biotechnologies support in forest sector for providing economic security of the state," Asian Social Science, 2015, V. 11, № 20, pp. 41-48. 